Research article

\title{
EFFECTS OF LOSARTAN, TEMPOL, AND THEIR COMBINATION ON RENAL NITRIC OXIDE SYNTHASES IN THE ANIMAL MODEL OF CHRONIC KIDNEY DISEASE
}

\author{
KARANOVIC Danijela ${ }^{1}$, GRUJIC-MILANOVIC Jelica ${ }^{1}$, MILORADOVIC Zoran ${ }^{1}$, \\ IVANOV Milan ${ }^{1}$, JOVOVIC Djurdjica ${ }^{1}$, VAJIC Una-Jovana ${ }^{1}$, CIROVIC Sanja ${ }^{2}$, \\ MARKOVIC-LIPKOVSKI Jasmina ${ }^{2}$, MIHAILOVIC-STANOJEVIC Nevena ${ }^{1 *}$
}

${ }^{1}$ Institute for Medical Research, University of Belgrade, Belgrade, Serbia;

${ }^{2}$ Institute of Pathology, Faculty of Medicine, University of Belgrade, Belgrade, Serbia

(Received 12 December 2016, Accepted 26 May 2017)

\begin{abstract}
Down-regulation of nitric oxide synthase (NOS) and NO deficiency in the kidneys have been implicated in the pathogenesis of chronic kidney disease (CKD). In this study we examined the effects of losartan, tempol, and combined treatment on three NOS isoforms expressions, kidney NO content and NOS correlation with renal function and structure in the early stage of adriamycin (ADR)-induced CKD in spontaneously hypertensive rats (SHR). Rats were divided into control group, and four other groups which were treated with ADR and received vehicle, losartan (L, angiotensin II type 1 receptor blocker), tempol ( $\mathrm{T}$, redox-cycling nitroxide) or $\mathrm{T}+\mathrm{L}$ treatment (by gavage) in a six-week study. Reduction of all NOS isoforms expressions were significantly improved by losartan or tempol, and correlated with proteinuria amelioration. Combined treatment induced down-regulation of constitutive NOS isoforms, whilst inducible NOS was up-regulated and followed by increased nitrite content and a significant decline in the glomerular filtration rate. Losartan or tempol prevented ADR-induced neoexpression of vimentin in the glomeruli and tubulointerstital areas, whereas de novo vimentin expression was still observed in the atrophic tubules and in the interstitial fibroblasts and myofibroblasts in combined treatment. It can be concluded that single treatments, contrary to combined, were effective in improving NO bioavailability and slowing down the progression of CKD.
\end{abstract}

Key words: adriamycin nephropathy, hypertension, nitric oxide synthase, losartan, tempol

\section{INTRODUCTION}

Nitric oxide (NO) is a free radical molecule formed by the conversion of L-agrinine to L-citruline by NO synthase (NOS) [1], has multiple roles involving cell signaling, vasodilatation, inflammation, tissue injury and cell defense [1,2]. In the kidney, NO

\footnotetext{
*Corresponding author: e-mail: nevena@imi.bg.ac.rs
} 
is implicated in the regulation of glomerular capillary pressure, glomerular filtration and renal blood flow [2,3]. All three isoforms of NOS, endothelial NOS (eNOS), neuronal NOS (nNOS) and inducible NOS (iNOS), have been identified in the kidney $[4,5]$. The constitutive forms of NOS, eNOS and nNOS, produce small quantities of NO, which is important for the regulation of glomerular microcirculation and the inhibition of platelet aggregation and adhesion, whereas iNOS, which can be induced by various cytokines and endotoxins, produces large quantities of $\mathrm{NO}$ with cytotoxic effects [2]. In the kidney constitutive NOS isoforms are expressed in physiological conditions, eNOS is mainly distributed in glomerular endothelial cells, afferent and efferent arterioles, and vasa recta in the medulla [2], whereas nNOS is restricted to the macula densa, efferent arterioles and Bowman's capsule [6]. The iNOS was found mainly in the tubules in the normal renal tissue [7-9].

NOS deficiency and decrease in NO production occur by multiple mechanisms and contribute to the pathogenesis and progression of chronic kidney disease (CKD) [10]. Previous studies reported that the inhibition of eNOS, nNOS or iNOS, either by using a selective inhibitor or knockout mice for particular enzyme, exacerbate renal injury and accelerate the progression of glomerular damage and proteinuria in different animal models of CKD [9,11-15]. Down-regulation of nNOS expression and following decrease of urinary nitrate/nitrite content were ameliorated by an angiotensin II type 1 receptor (AT1R) blocker, losartan in nephrectomized (5/6 Nx) rats [16]. Captopril, angiotensin-converting enzyme inhibitor (ACEI), also caused an increase in urinary excretion of NO products and abrogated proteinuria and hypertension in the $5 / 6$ $\mathrm{Nx}$ rats [7], pointing to a direct relationship between angiotensin II (AngII) and renal NOS in CKD.

It has been shown that antioxidant treatment in rats with renal ablation $(5 / 6 \mathrm{Nx})$ reverse down-regulations of NOS isoforms [5], prevent superoxide production [17], and protect against renal dysfunction and injury [18], presumably by reducing oxidative stress. Furthermore, tempol, a cell permeable redox-cycling nitroxide [19], elicited higher increase of renal eNOS expression than losartan, and showed an antiinflammatory effect associated with antioxidant action in the kidneys of rats submitted to sodium overload [20].

Previous studies performed by this group of authors showed that spontaneously hypertensive rats (SHR) with adriamycin (ADR)-induced nephropathy, when treated with captopril [21] or losartan [22,23] improved hypertension, one of the factors involved in CKD progression. The second risk factor responsible for CKD progression, proteinuria, was also attenuated with losartan in the early phase of the disease, followed by improvement of oxidative stress, tubular structure and restoration of anti-inflammatory defense, however, tempol was more successful in reducing systemic oxidative stress, proteinuria and glomerulosclerosis [23]. Interestingly, combined treatment did not overcome these benefits of single treatments in slowing down the progression of CKD, probably because it failed to improve bioavailability of $\mathrm{NO}$ in this experimental model. 
Thus, the aim of the present study was to investigate the effects of chronic single and combined treatments with losartan and tempol on renal NOS isoforms expressions and their correlation with renal function and structure in SHR with early ADR-induced nephropathy.

\section{MATERIALS AND METHODS}

\section{Experimental protocol}

Adult female SHR (six-month-old, 180-200 g body weight (b.w.)) were housed under standard conditions at the Institute for Medical Research, Belgrade, Serbia. Tap water and standard rat chow (Veterinarski zavod Subotica, Serbia) were provided ad libitum. The experimental protocol was in accordance with the National Law on Animal Welfare ("Sl.gl.RS" No6/10) and approved by the Ethic Committee of the Institute for Medical Research, University of Belgrade, Serbia and Veterinary Directorate, Ministry of Agriculture and Environmental Protection, Republic of Serbia (No. 323-07-00318/2015-05). All surgical interventions were performed under anesthesia (sodium pentobarbital, $35 \mathrm{mg} / \mathrm{kg}$ b.w., intraperitoneally (i.p.)), and all efforts were made to minimize suffering.

The rats were randomly divided into five groups according to previous non-invasive (Physiograph Four, Narco Bio-system Houston, TX, USA) systolic blood pressure measurement. Four experimental groups received ADR ( $2 \mathrm{mg} / \mathrm{kg}$ b.w.) twice in a 21 day interval, intravenously (femoral vein) under anesthesia. Control group (SHC) was injected with a comparable volume of $0.9 \%$ saline. After the second injection of saline or ADR, SHC and SHADR received tap water, while SHADR+L, SHADR+T, and SHADR+T+L groups received losartan (L, $10 \mathrm{mg} / \mathrm{kg} /$ day b.w., Dup 753, DuPont, Wilmington De.), tempol (T, $100 \mathrm{mg} / \mathrm{kg} /$ day b.w., Sigma-Aldrich), or both (T+L) by gavage during the next six weeks, respectively. At the end of the study, rats were placed in individual metabolic cages for 24-hour urine collection. After this period, blood pressure measurement, followed by blood sample and kidney collection were performed on anaesthetized animals.

\section{Blood pressure}

Mean blood pressure (MBP) was measured in anesthetized rats as previously described [23].

\section{Sample collection}

Blood samples were obtained by abdominal aorta puncture, using an anticoagulantEDTA (Ethylenediaminetetraacetic acid disodium salt dehydrate, Division of ICN Biomedicals, Inc.Cleveland, Ohio) and centrifuged at $4000 \mathrm{rpm}, 4^{\circ} \mathrm{C}$ for $20 \mathrm{~min}$. 
Plasma was collected and stored at $-20^{\circ} \mathrm{C}$ until assaying. Kidneys were harvested, weighted and stored at $-70^{\circ} \mathrm{C}$ for later analysis.

\section{Estimation of kidney function parameters}

Urine and plasma creatinine, as well as urine protein concentrations were measured by an automatic COBAS INTEGRA 400 plus analyzer (Hoffmann-La Roche, Leitch Diagnostic, Germany). Creatinine clearance $\left(\mathrm{C}_{\mathrm{cr}}\right)$ was assessed to evaluate the glomerular filtration rate (GFR), and calculated according to a standard formula. Urine protein excretion $\left(\mathrm{P}_{\mathrm{exc}}, \mathrm{mg} / \mathrm{min} / \mathrm{kg}\right)$ was used for the assessment of proteinuria.

\section{Immunohistochemisry}

Immunostaining was applied on $5 \mu \mathrm{m}$ thick paraffin sections as previously described [23] using primary antibodies: nNOS (Chemicon International, AB5380, dilution 1:100), iNOS (Sigma-Aldrich, SAB4502011, dilution 1:100), eNOS (Invitrogen by Thermo Fisher Scientific, PA1-037, dilution 1:100), and vimentin (Millipore, MAB3400, dilution 1:200).

\section{Western blotting}

For Western blotting the kidneys were homogenized in lysis buffer, as previously described [23] and stored at $-70^{\circ} \mathrm{C}$ until analysis. Equal amounts of protein samples were run on $8 \%$ polyacrylamide gels and transferred to nitrocellulose membranes (Appli-Chem GmbH, Darmstadt, Germany). Membranes were probed with primary antibodies to nNOS (1:1000, AB5380 Chemicon International), iNOS (1:1000, SAB4502011 Sigma-Aldrich), eNOS (1:1000, PA1-037 Invitrogen by Thermo Fisher Scientific), and actin (1:1000, Sigma-Aldrich, A5060). Peroxidase-conjugated goat antirabbit immunoglobulin (1:40.000, Sigma-Aldrich, A0545) was used as the secondary antibody. Western blots were developed using the enhanced chemiluminescence reagent system (GE Healthcare, Amersham, UK) according to the manufacturer's instructions. The content of the target proteins in the tissue extracts were estimated by the densitometry of scanned immunoblot bands using the Image Master Total Lab (GE Healthcare) software.

\section{Determination of NO levels in kidney homogenates}

Kidney homogenates were assayed for $\mathrm{NO}_{\mathrm{x}}$ content by the Griess reagent method [24]. Nitrate reductase (NAD $[\mathrm{P}] \mathrm{H})$ from Aspergillus niger was used for conversion of nitrate $\left(\mathrm{NO}_{3}^{-}\right)$to nitrite $\left(\mathrm{NO}_{2}^{-}\right)$.

\section{Statistical analysis}

Data are presented as mean \pm SEM. One-way analysis of variance (ANOVA) was used for multiple comparisons between experimental groups, and Fisher LSD test was 
performed as post hoc multiple comparison test (Statistica 8). The Pearson correlation between the examined parameters was also determined. $P$-value $<0.05$ was considered significant.

\section{RESULTS}

\section{Blood pressure and kidney function}

MBP and parameters of renal function are presented in Table 1. ADR did not affect MBP or $\mathrm{C}_{\mathrm{cr}}$ in SHR with early stage of ADR nephropathy. MBP was significantly reduced only in the SHADR+L group compared to both SHC and SHADR. Massive proteinuria was observed in SHADR group, and it was significantly reduced following all treatments. However, the levels of $\mathrm{P}_{\text {exc }}$ in $\mathrm{SHADR}+\mathrm{L}$ and $\mathrm{SHADR}+\mathrm{T}+\mathrm{L}$ groups were significantly higher than in SHC, while in SHADR $+\mathrm{T}$ it was almost similar to control group. Contrary to both single treatments, losartan and tempol in combination $(\mathrm{SHADR}+\mathrm{T}+\mathrm{L})$ induced a significant reduction of $\mathrm{C}_{\mathrm{cr}}$ compared to $\mathrm{SHC}$ and SHADR+T group.

\section{Immunoperoxidase staining and western blot analysis of iNOS, nNOS, and eNOS}

Immunohistochemical localization of eNOS was mainly detected in the glomeruli of studied groups (Figure 1A-E). In control group glomerular endothelial cells were positively stained for eNOS (Figure 1A). In contrast, in SHADR group eNOS staining was clearly lower, whereas it was hardly detected in the area of mesangial expansion of glomeruli with moderate lesions or in the sclerotic glomeruli (Figure 1B). The extent of staining for eNOS after losartan treatment was clearly increased in the glomeruli (Figure 1C). The expression pattern of eNOS in the renal tissue of $\mathrm{SHADR}+\mathrm{T}$ group was similar to that in SHADR $+\mathrm{L}$ group (Figure 1D). Combined treatment showed lower, almost completely absent eNOS in the glomeruli (Figure $1 \mathrm{E})$. The nNOS positive staining was prominent in the macula densa of SHC group (Figure 1F), but only rarely observed in SHADR (Figure 1G), and strongly expressed in both SHADR $+\mathrm{L}$ and SHADR $+\mathrm{T}$ (Figure $1 \mathrm{H}, \mathrm{I}$ ), whereas in $\mathrm{SHADR}+\mathrm{T}+\mathrm{L}$ group the expression was clearly lower (Figure 1J). The iNOS positive staining was widely distributed in renal tubules. In the control group prominent iNOS staining was noticed in the proximal and distal tubules and collecting ducts (Figure $1 \mathrm{~K}$ ). In contrast, the iNOS immunostaining was lower in the renal tubules of ADR-treated SHR (Figure 1L). In epithelial tubular cells, losartan or tempol (Figure 1M, N) induced a strong positive iNOS staining, whereas combined treatment did not (Figure 1O).

Results obtained from the western blot studies of nNOS, eNOS, and iNOS protein expressions are presented in Figure 2. The expression of iNOS was significantly suppressed, while nNOS and eNOS expressions were markedly, but not significantly reduced in ADR-treated SHR. Losartan or tempol treatments significantly increased the expressions of all NOS isoforms in the kidney compared with the SHADR group. 

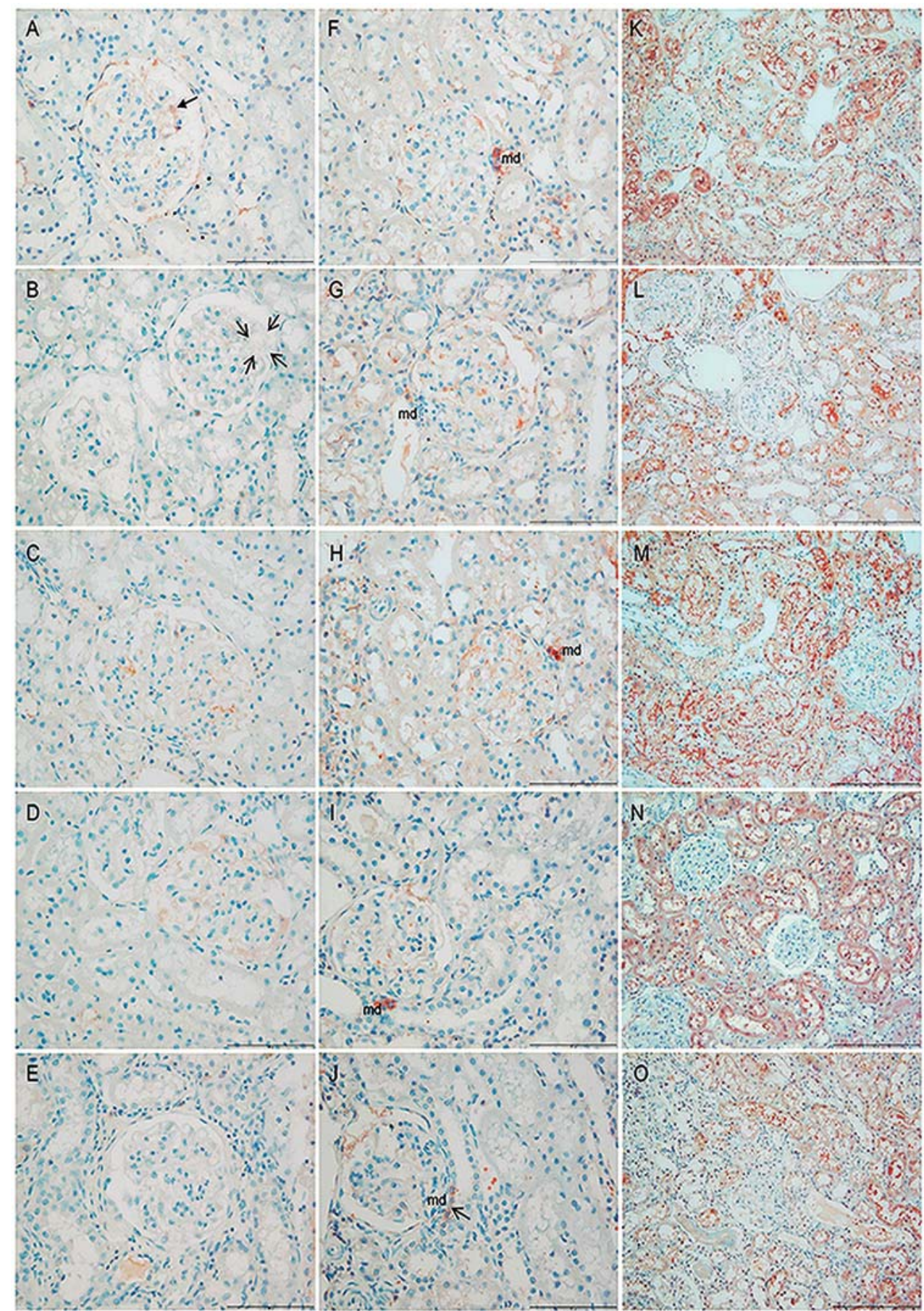

Figure 1. Immunohistochemical staining for NOS isoforms in renal tissue in the experimental groups. Original magnification $\mathrm{x} 40$ in $(\mathrm{A}-\mathrm{J})$, scale bar $=100 \mu \mathrm{m}$; $\mathrm{x} 20$ in $(\mathrm{K}-\mathrm{O})$, scale bar $=200$ 
$\mu \mathrm{m}$. Immunohistochemistry for eNOS (A-E): In SHC group the eNOS positive staining is observed in glomerular endothelial cells (thick arrow) (A). In SHADR group eNOS staining is clearly lower and hardly detected in sclerotic glomerulus (B, left one); note the absence of eNOS staining in the area of mesangial expansion (the area surrounded by thin arrows) in the upper-right glomerulus (B). The eNOS staining is clearly increased in glomeruli of SHADR+L group (C). The expression pattern of eNOS in the renal tissue of SHADR+T (D) is similar to that in SHADR $+\mathrm{L}$ group $(\mathrm{C})$. Combined treatment showed lower, almost completely absent of glomerular eNOS expression (E). Immunohistochemistry for nNOS (F-J): In SHC group strong nNOS expression is observed in the macula densa (F). In SHADR group only rare cells are positive for nNOS in macula densa $(G)$. The prominent nNOS staining is found in SHADR $+\mathrm{L}(\mathrm{H})$ and SHADR+T (I) groups, whereas in SHADR+T+L group the nNOS expression is clearly lower in macula densa (J). Immunohistochemistry for iNOS (K-O): The iNOS protein is widely distributed in renal tubular cells of SHC group (K). The expression of iNOS is lower in injured renal tubules of SHADR group (J). The SHADR+L group (M) exhibits strong iNOS immunostaining in proximal and distal tubules and collecting ducts, and similar pattern is observed in SHADR+T $(\mathrm{N})$. In SHADR $+\mathrm{T}+\mathrm{L}(\mathrm{O})$ group the iNOS expression is clearly lower in areas with moderate renal injury. SHC - control group, SHADR - SHR treated with adriamycin, $\mathrm{L}$ - losartan, T - tempol, md - macula densa.

In addition, the eNOS expression was significantly increased in both, SHADR $+\mathrm{L}$ and SHADR+T groups compared to the control group. Tempol induced a stronger increase $(p<0.05)$ of iNOS expression than losartan. In contrast, the expressions of constitutive NOS isoforms in SHADR +T+L group were significantly lower than that found in the control group, or after both single treatments, and similar to SHADR group. Furthermore, combined treatment significantly increased the expression of iNOS in SHADR+T+L group to the level near the control group, even though it still remained significantly lower than the one found in the SHADR+T group.
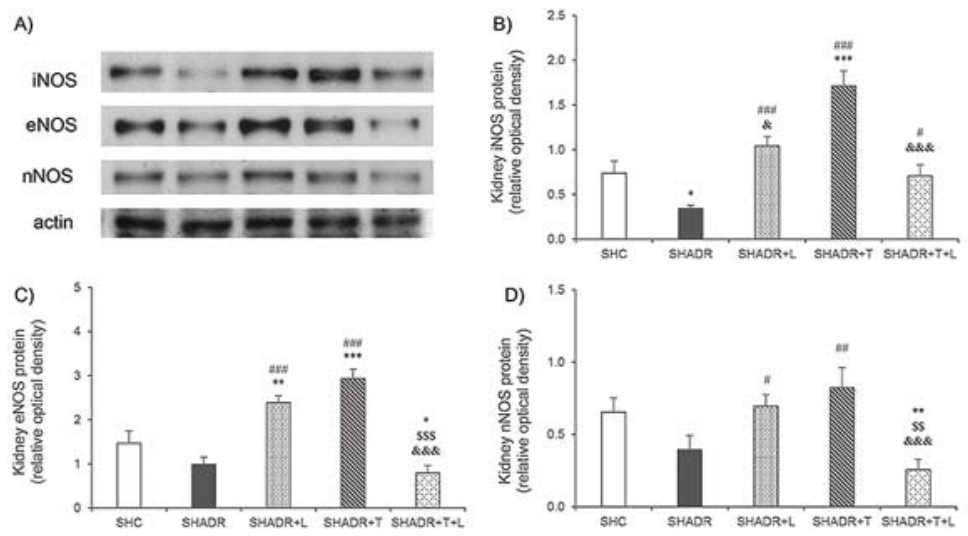

Figure 2. Kidney NOS isoforms protein levels in the experimental groups. (A) Representative Western blots showing specific band for iNOS, eNOS, nNOS, and actin as an internal control. The quantitative data, calculated as the relative density of the target protein to that of actin, are presented in (B-D): (B) iNOS, (C) eNOS, and (D) nNOS. ${ }^{*} p<0.05,{ }^{* *} p<0.01,{ }^{* * *} p<0.001$ vs. SHC; ${ }^{\#} p<0.05,{ }^{\# \#} p<0.01,{ }^{\# \# \#} p<0.001$ vs. SHADR; ${ }^{\$ \$} p<0.01,{ }^{\$ \$} p<0.001$ vs. SHADR $+\mathrm{L}$; ${ }^{\&} p<0.05,{ }^{\& \& \&} p<0.001$ vs. SHADR $+\mathrm{T} ; \mathrm{n}=6$ animals per group. Data represent mean \pm SEM. SHC - control group, SHADR - SHR treated with adriamycin, L - losartan, T - tempol. 


\section{Renal NO content}

At the end of the six-week period, a significant reduction of the $\mathrm{NO}_{\mathrm{x}}$ content, which was associated with a drop in nitrate level, was observed in the kidney of the SHADR group (Table 1). Losartan reverted the $\mathrm{NO}_{\mathrm{x}}$ level to the control value. Contrary to the single treatment, tempol in combination with losartan induced a significant increase of nitrite content, resulting in a strong rise of $\mathrm{NO}_{\mathrm{x}}$ level $(p<0.05)$ compared to the value in the kidney of SHADR group.

Table 1. Blood pressure, kidney function and renal NO content in the experimental groups

\begin{tabular}{|c|c|c|c|c|c|}
\hline & $\begin{array}{l}\text { SHC } \\
(n=8)\end{array}$ & $\begin{array}{c}\text { SHADR } \\
(\mathrm{n}=8)\end{array}$ & $\begin{array}{l}\text { SHADR+L } \\
\quad(n=8)\end{array}$ & $\begin{array}{c}\text { SHADR+T } \\
(n=8)\end{array}$ & $\begin{array}{l}\text { SHADR }+T+L \\
(n=8)\end{array}$ \\
\hline $\mathrm{MBP}(\mathrm{mmHg})$ & $164.38 \pm 10.46$ & $160.63 \pm 9.94$ & $136.14 \pm 4.67^{* \#}$ & $143.13 \pm 8.77$ & $144.75 \pm 7.20$ \\
\hline $\mathrm{C}_{\mathrm{cr}}(\mathrm{ml} / \mathrm{min} / \mathrm{kg})$ & $4.19 \pm 0.46$ & $3.58 \pm 0.43$ & $3.04 \pm 0.31$ & $3.98 \pm 0.68$ & $2.43 \pm 0.56^{* \&}$ \\
\hline $\mathrm{P}_{\text {exc }}(\mathrm{mg} / \mathrm{min} / \mathrm{kg})$ & $0.02 \pm 0.00$ & $1.10 \pm 0.24^{* * *}$ & $0.51 \pm 0.09^{* * \# \#}$ & $0.18 \pm 0.03$ \#\#\# & $0.38 \pm 0.08$ *\#\#\# \\
\hline $\mathrm{NO}_{3}^{-}(\mu \mathrm{mol} / \mathrm{mg}$ prot $)$ & $76.57 \pm 5.29$ & $56.30 \pm 5.59^{*}$ & $65.50 \pm 5.04$ & $54.99 \pm 5.67^{*}$ & $71.90 \pm 8.44$ \\
\hline $\mathrm{NO}_{2}^{-}(\mu \mathrm{mol} / \mathrm{mg}$ prot $)$ & $4.57 \pm 0.56$ & $5.09 \pm 0.35$ & $6.80 \pm 0.97$ & $4.88 \pm 0.36$ & $8.55 \pm 1.48^{* * \# \# \& \& 8}$ \\
\hline $\mathrm{NO}_{x}(\mu \mathrm{mol} / \mathrm{mg}$ prot $)$ & $81.14 \pm 5.32$ & $61.39 \pm 5.67^{*}$ & $72.30 \pm 5.65$ & $59.88 \pm 5.78^{*}$ & $80.45 \pm 9.66^{\# \&}$ \\
\hline
\end{tabular}

$\mathrm{MBP}$ - mean blood pressure, $\mathrm{C}_{\mathrm{cr}}$ - creatinine clearance, $\mathrm{P}_{\mathrm{exc}}$ - protein urine excretion, $\mathrm{NO}_{\mathrm{x}}-$ sum of renal $\mathrm{NO}_{3}{ }_{3}^{-}$and $\mathrm{NO}_{2}{ }^{-}$content.

${ }^{*} p<0.05,{ }^{* *} p<0.01,{ }^{* * *} p<0.001$ vs. SHC; ${ }^{\#} p<0.05,{ }^{\# \#} p<0.01,{ }^{\# \# \#} p<0.001$ vs. SHADR, $\& p<0.05, \& \& p<0.01$ vs. SHADR $+\mathrm{T}$;

$\mathrm{n}=8$ animals per group. Data represent mean \pm SEM. SHC - control group, SHADR - SHR treated with adriamycin, $\mathrm{L}-$ losartan, $\mathrm{T}-$ tempol.

\section{Immunolocalization of vimentin}

Control group showed normal expression of vimentin in the glomeruli, predominantly in the podocytes, arterioles, and in occasional interstitial fibroblasts (Figure 3A, F), and the epithelial cells of the tubules were negative (Figure 3K). In ADR-treated SHR increased vimentin expression was observed in the podocytes, mesangial cells, and parietal epithelial cells of Bowman's capsule in the sclerotic glomeruli (Figure $3 B, G)$. In addition, vimentin neoexpression was observed in the tubulointerstitial areas, where dedifferentiated tubular epithelial cells, fibroblasts and myofibroblasts stained positive for vimentin (Figure 3L). Both single treatments either with losartan (Figure 3C, H) or tempol (Figure 3D, I) clearly decreased vimentin expression in all glomeruli, while tubules were negative for vimentin (Figure 3M, N). Positive vimentin immunostaining was observed in glomeruli of SHADR $+\mathrm{T}+\mathrm{L}$ group (Figure $3 \mathrm{E}, \mathrm{J}$ ) in a similar pattern as in $\mathrm{SHADR}+\mathrm{T}$ and $\mathrm{SHADR}+\mathrm{L}$ groups, while immunodistribution of vimentin in interstitial fibroblasts and myofibroblasts (Figure 3O) of this group were the same, but with lower intensity compared to SHADR group. Furthermore, moderate de novo expression of vimentin in the dedifferentiated tubules was observed in SHADR $+\mathrm{T}+\mathrm{L}$ group (Figure 3O) compared to SHADR group (Figure 3L). 


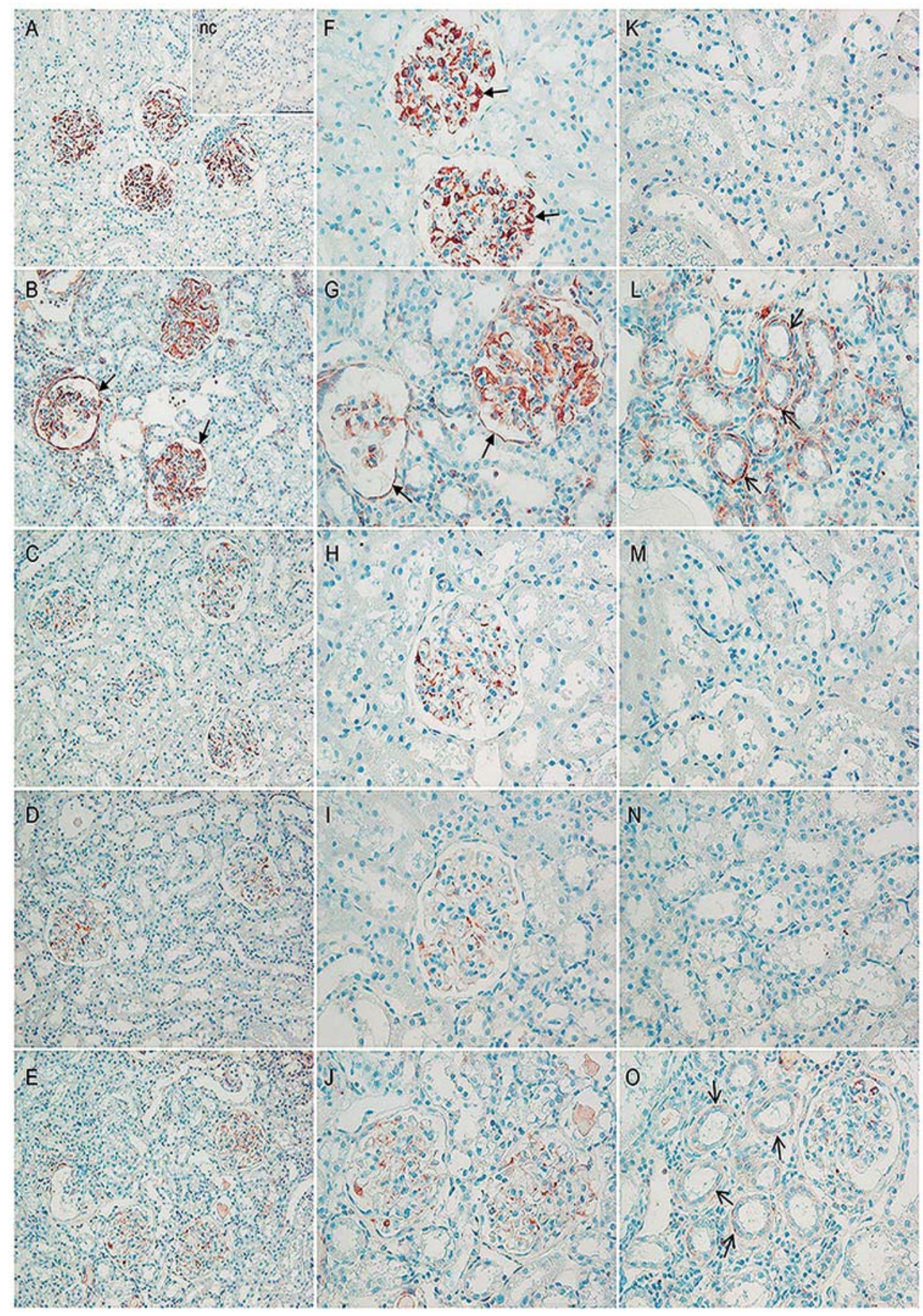

Figure 3. Immunohistochemical staining for vimentin in the renal tissue in the experimental groups. Original magnification: $\mathrm{x} 20$ in (A-E), scale bar $=200 \mu \mathrm{m}$; and $\mathrm{x} 40$ in (nc, F-O), scale $\mathrm{bar}=100 \mu \mathrm{m}$. In SHC group the normal vimentin expression is observed in podocytes (thick 
arrows) (A, F), while epithelial cells of the tubules do not show expression of vimentin (K). In the SHADR group increased vimentin expression is observed in the podocytes, mesangial cells, and in the parietal epithelial cells of Bowman's capsule (thick arrows) of the sclerotic glomeruli (B, G). Notice the neoexpression of vimentin in the tubulointerstitial areas, where dedifferentiated tubular epithelial cells, fibroblasts and myofibroblasts (thin arrows) stain positive for vimentin (L). Losartan clearly decrease vimentin expression in all glomeruli $(\mathrm{C}, \mathrm{H})$ and tubules are negative for vimentin $(\mathrm{M})$ in SHADR $+\mathrm{L}$ group. Similar pattern of vimentin expression is also found in SHADR $+\mathrm{T}$ group $(\mathrm{D}, \mathrm{I}, \mathrm{N})$. In SHADR $+\mathrm{T}+\mathrm{L}$ group moderate de novo vimentin expression is observed in the proximal tubules, whereas in the interstitium fibroblasts and myofibroblasts (thin arrows) were stained positive for vimentin $(\mathrm{O})$, while in glomeruli $(\mathrm{E}, \mathrm{J})$ vimentin is expressed similarly as in SHADR+T (I) and SHADR+L $(\mathrm{H})$ groups. SHC - control group, SHADR - SHR treated with adriamycin, L - losartan, T tempol, nc - negative control staining.

\section{Correlation analysis of parameters}

The correlations among the examined parameters are presented in Table 2. Proteinuria was negatively correlated with the expression of nNOS, eNOS, and iNOS. In addition, there was a strong positive correlation between three NOS isoforms in the kidneys. MBP was not in correlation with proteinuria nor NOS isoforms expression in this experimental model.

Table 2. The correlation among MBP, $\mathrm{P}_{\text {exc }}$ and renal NOS protein expression in all experimental groups

\begin{tabular}{lcccc}
\hline & MBP (mmHg) & iNOS/actin & eNOS/actin & nNOS/actin \\
\hline $\mathrm{P}_{\text {exc }}(\mathrm{mg} / \mathrm{min} / \mathrm{kg})$ & $\mathrm{r}=0.0032$ & $\mathrm{r}=-0.4020$ & $\mathrm{r}=-0.3750$ & $\mathrm{r}=-0.4383$ \\
& $\mathrm{p}=0.987$ & $\mathrm{p}=0.028$ & $\mathrm{p}=0.041$ & $\mathrm{p}=0.015$ \\
iNOS/actin & $\mathrm{r}=-0.1910$ & & $\mathrm{r}=0.7399$ & $\mathrm{r}=0.6526$ \\
& $\mathrm{p}=0.312$ & & $\mathrm{p}=0.000$ & $\mathrm{p}=0.000$ \\
eNOS/actin & $\mathrm{r}=-0.3407$ & $\mathrm{r}=0.7399$ & & $\mathrm{r}=0.8455$ \\
& $\mathrm{p}=0.065$ & $\mathrm{p}=0.000$ & & $\mathrm{p}=0.000$ \\
nNOS/actin & $\mathrm{r}=-0.0798$ & $\mathrm{r}=0.6526$ & $\mathrm{r}=0.8455$ & \\
& $\mathrm{p}=0.675$ & $\mathrm{p}=0.000$ & $\mathrm{p}=0.000$ & \\
\hline
\end{tabular}

MBP - mean blood pressure, $\mathrm{P}_{\text {exc }}$ - protein urine excretion, NOS - nitric oxide synthase, $\mathrm{n}-$ neuronal, $\mathrm{i}$ - inducible, e - endothelial. Marked correlations are significant at $p<0.05, \mathrm{~N}=30$.

\section{DISCUSSION}

In the present study, we demonstrated that the expression of NOS isoforms in the kidney were strongly depressed in the early stage of ADR nephropathy. Simultaneous down-regulations of all NOS isoforms expression were significantly improved by the treatment with AT1R blocker (losartan) or antioxidant (tempol) showing a strong correlation with proteinuria amelioration in ADR-treated SHR. In contrast, when used in combination losartan and tempol induced a significant increase of iNOS expression 
and no changes in diminished expression of nNOS and eNOS in SHADR $+\mathrm{T}+\mathrm{L}$ group. The NOS deficiency in the SHADR group was followed by a significant reduction of $\mathrm{NO}_{\mathrm{x}}$ content in the kidney, which was restored by losartan. Contrary to single treatment, tempol in combination with losartan induced a significant increase of nitrite level in the renal tissue. Furthermore, even though combined treatment lowered proteinuria, a significant fall in GFR still existed in SHADR+T+L group. To our knowledge, this is the first study of renal distribution of three NOS isoforms, as well as vimentin after combined and single losartan and tempol treatments, pointing to a relationship between NOS attenuation and the progression of kidney disease in SHR with an early stage of ADR nephropathy.

The findings are in accordance with previous reports from Rangan et al., who showed that continuous oral administration of two structurally diverse selective inhibitors of iNOS exacerbated the progression of ADR-induced nephropathy indicating that endogenous iNOS-derived NO has a protective role in proteinuric tubulointerstitial injury [12]. Moreover, the inhibition of iNOS by aminoguanidine resulted with more structural changes in the renal cortex of diabetic rats [9]. The eNOS deficiency exacerbates renal injury in the remnant kidney model [25] and accelerates diabetic kidney damage $[14,26]$. Likewise, Sun et al. showed that glomerular endothelial dysfunction and damage precede podocyte damage in ADR-induced nephropathy in C57BL/6 mice with eNOS deficiency [11], indicating the importance of glomerular endothelial cells in the pathogenesis of proteinuria and development of glomerulosclerosis, tubulointerstitial fibrosis and inflammation. Furthermore, the reduction in nNOS protein abundance correlates with increasing glomerular damage and decreasing renal function in different animal models of CKD $[13,27,28]$, suggesting that the renal nNOS response to kidney damage may be an important determinant of the susceptibility to CKD progression.

Podocytes in the glomerulus express three intermediate filament proteins, namely nestin, vimentin, and desmin, which are up-regulated in puromycin aminonucleoside nephrosis [29]. We have recently (2016) documented overexpression and diffused glomerular distribution of nestin in SHR with early ADR nephropathy [23]. In this study, vimentin was located predominantly in the podocytes of SHR, and ADR application induced a strong up-regulation of vimentin expression in the podocytes, mesangial cells, parietal epithelial cells of Bowman's capsule in the sclerotic glomeruli, and scattered peritubular positive staining areas were also observed. Likewise, with the same dose of ADR, Van Beneden et al. showed the same pattern of vimentin expression in $W$ istar rats [30]. These data lead to the conclusion that the preexistence of hypertension in our model could not be accounted for glomerular and tubular remodeling in the early phase of ADR nephropathy. Other studies have shown that the up-regulation of vimentin expression was observed in the renal tubules and interstitial areas in cyclosporine A-induced nephrotoxicity [31,32]. Since vimentin is used as a marker of tubulointerstitial injury and epithelial-mesenchymal transition, the neoexpression of vimentin in the proximal tubules is an unequivocal signal of 
injury and regeneration in these areas [31,33]. Furthermore, Bravo et al. showed that NOS inhibition by L-NAME induced a significant increase of vimentin expression in the kidneys of Sprague-Dawley rats. These data are in agreement with our findings of vimentin distribution in SHADR kidney, and ADR-attenuated NOS expression points to the important role of NO deficiency in the pathogenesis and progression of renal disease in the early stage of ADR nephropathy. All of the treatments decreased vimentin expression in a significant degree, while losartan and tempol single treatments showed greater effect in preventing vimentin positive staining in tubules of ADR pretreated SHR rats.

In the present study, we showed that losartan, as a specific antagonist of AT1 receptors, besides the antihypertensive effect, induced a significant improvement of all three NOS isoforms expressions and restored $\mathrm{NO}_{\mathrm{x}}$ content in the kidney, which were associated with proteinuria amelioration in the SHADR $+\mathrm{L}$ group. Previous reports also indicated that the mechanism for impaired $\mathrm{NO}$ production in $\mathrm{CKD}$ may involve the renin angiotensin system (RAS). Namely, the 5/6 Nx-induced down-regulation of nNOS protein expression was partially restored in the renal cortex following treatment with losartan [16]. Losartan also normalized AngII expression and simultaneously enhanced eNOS expression in the renal cortex and medulla in rats submitted to sodium overload [20]. However, contrary to our study, Ji et al. showed that blocking RAS by losartan slowed the progression of renal injury in rats subjected to unilateral nephrectomy and ADR injection, $6 \mathrm{mg} / \mathrm{kg}$, by down-regulating the expression of iNOS [34]. Such discrepancy could be the result of different experimental design and difference in dose of ADR used to induce various degrees of CKD.

eNOS deficiency accelerates renal injury induced by 5/6 Nx [18] and it could be ameliorated by a combination of L-arginine and antioxidants (vitamin $\mathrm{C}$ and $\mathrm{E}$ ). Previous studies have reported similar results $[5,17,20]$. In this study, tempol induced a significant increase of all three NOS isoforms expressions and abolished proteinuria in SHR with ADR nephropathy, even though the nitrate level in the kidney was reduced. Our previous findings showing that tempol increased urinary nitrate excretion [23] support this notion. Taking into account that renal NO production represents just a small fraction of total NO [17], since the kidney is a minor source of NO generation, dissociation between total and renal NO production was also observed in different forms of CKD [2].

The major finding of this study is that a combination of losartan and tempol, contrary to single treatments, induced a down-regulation of both constitutive NOS isoforms and a significant increase of iNOS expression, which was accompanied by a significant increase of nitrite production in the kidney of SHR with ADR-induced nephropathy. In addition, in SHADR $+\mathrm{T}+\mathrm{L}$ group proteinuria was lower compared to the SHADR group, but still significantly higher than in the control group, and followed by a significant decline of GFR. Similar findings were obtained by Furusu et al. who showed that the degree of glomerular injury negatively correlated with eNOS and positively with iNOS expression in proliferative glomerulonephritis [4]. Nonetheless, Ozen et 
al. suggested that increased production of nitrite by iNOS might be responsible for proteinuria in ADR-induced nephropathy in $W$ istar rats [35]. Since the half-life of NO is very short, the biological effects of $\mathrm{NO}$ depend on the concentration at the site of action and the specific location of NO production. Based on the fact that small quantities of $\mathrm{NO}$ are generated by constitutive NOS isoforms, while large quantities of NO are synthesized by iNOS [2], we presume that in this study the significantly increased nitrite level in the kidney is the consequence of elevated iNOS activity with concurrent reduction of both constitutive NOS isoforms in SHADR+T+L group. Thus, $\mathrm{NO}_{2}^{-}$could react with $\mathrm{O}_{2}^{-}$and yield peroxynitrite anion, which is a strong oxidant that could react with and modify various molecules, such as lipids, DNA, and proteins, causing structural and functional changes and leading to increased renal injury and progression of kidney disease. Taken together, these findings suggest that the combination of AT1R blocker and tempol in ADR-induced nephropathy in SHR could induce the alteration in the expression of NOS isoforms in the kidneys in a way that contributes to the progression of renal disease. Our results also suggest that NOS could play a critical role in the pathogenic mechanisms of progressive kidney disease and that NO may also participate in the process of glomerular injury through different mechanisms.

In conclusion, in the early stage of CKD in SHR, ADR caused down-regulation of renal NOS isoforms expressions, deficiency of kidney NO content, vimentin neoexpression and massive proteinuria, independently of blood pressure. Losartan or tempol single treatments, contrary to their combination, were more effective in ameliorating proteinuria, renal vimentin and NOS protein isoforms expressions and in slowing-down the progression of CKD. Further studies are needed to clarify the exact mechanism of interactions between AT1R blockade and tempol in stimulation of renal NO pathway and their effects on slowing down the progression of ADR nephropathy.

\section{Acknowledgment}

This work was supported by a Grant (Project OI175096) from the Ministry of Education, Science and Technological development of the Republic of Serbia.

\section{Authors' contributions}

NMS, DK and JGM made substantial contributions to conception and design of the study and were involved in drafting of the manuscript. ZM, NMS, JGM, MI, UJV and DK participated in the surgery of small experimental animals and in the acquisition of data. JML and SC carried out the histopathological studies. Analysis and interpretation of data were performed by NMS, DK and JGM. NMS and ĐJ critically revised the manuscript for important intellectual content. All authors read and approved the final manuscript. 


\section{Declaration of conflicting interests}

The author(s) declared no potential conflicts of interest with respect to the research, authorship, and/or publication of this article.

\section{REFERENCES}

1. Andrew PJ, Mayer B: Enzymatic function of nitric oxide synthases. Cardiovasc. Res. 1999, 43:521-531.

2. Raij L, Baylis C: Glomerular actions of nitric oxide. Kidney Int. 1995, 48:20-32.

3. Baylis C, Mitruka B, Deng A: Chronic blockade of nitric oxide synthesis in the rat produces systemic hypertension and glomerular damage. J. Clin. Invest. 1992, 90:278-281.

4. Furusu A, Miyazaki M, Abe K, Tsukasaki S, Shioshita K, Sasaki O, Miyazaki K, Ozono Y, Koji T, Harada T, Sakai H, Kohno S: Expression of endothelial and inducible nitric oxide synthase in human glomerulonephritis. Kidney Int. 1998, 53:1760-1768.

5. Vaziri ND, Ni Z, Oveisi F, Liang K, Pandian R: Enhanced nitric oxide inactivation and protein nitration by reactive oxygen species in renal insufficiency. Hypertension 2002, 39:135-141.

6. Bachmann S, Bosse HM, Mundel P: Topography of nitric oxide synthesis by localizing constitutive NO synthases in mammalian kidney. Am J Physiol 1995, 268:F885-F897.

7. Ashab I, Peer G, Blum M, Wollman Y, Chernihovsky T, Hassner A, Schwartz D, Cabili S, Silverberg D, Iaina A: Oral administration of L-arginine and captopril in rats prevents chronic renal failure by nitric oxide production. Kidney Int. 1995, 47:1515-1521.

8. Aiello S, Noris M, Todeschini M, Zappella S, Foglieni C, Benigni A, Corna D, Zoja C, Cavallotti D, Remuzzi G: Renal and systemic nitric oxide synthesis in rats with renal mass reduction. Kidney Int. 1997, 52:171-181.

9. Mazroa SA, Asker SA, El-Shafey S: Immunohistochemical Distribution of Inducible Nitric Oxide Synthase Enzyme (iNOS ) in the Renal Cortex of Control and Diabetic Adult Male Albino Rats and the Effect of iNOS Inhibition by Aminoguanidine. Egypt. J. Histol. 2009, 32:235-45.

10. Baylis C: Nitric oxide synthase derangements and hypertension in kidney disease. Curr. Opin. Nephrol. Hypertens. 2012, 21:1-6.

11. Sun YBY, Qu X, Zhang X, Caruana G, Bertram JF, Li: Glomerular endothelial cell injury and damage precedes that of podocytes in adriamycin-induced nephropathy. PLoS One 2013, 8:1-12.

12. Rangan GK, Wang Y, Harris DCH: Pharmacologic modulators of nitric oxide exacerbate tubulointerstitial inflammation in proteinuric rats. J Am Soc Nephrol. 2001, 12:1696-1705.

13. Muller V, Tain YL, Croker B, Baylis C: Chronic nitric oxide deficiency and progression of kidney disease after renal mass reduction in the C57Bl6 mouse. Am J Nephrol. 2010, 32(6):575-80.

14. Nakagawa T, Sato W, Glushakova O, Heinig M, Clarke T, Campbell-Thompson M, Yuzawa Y, Atkinson MA, Johnson RJ, Croker B: Diabetic endothelial nitric oxide synthase knockout mice develop advanced diabetic nephropathy. J Am Soc Nephrol. 2007, 18:539-550.

15. Kashiwagi M, Shinozaki M, Hirakata H, Tamaki K, Hirano T, Tokumoto M, Goto H, Okuda S, Fujishima M: Locally activated renin-angiotensin system associated with TGF-b1 
as a major factor for renal injury induced by chronic inhibition of nitric oxide synthase in rats. J Am Soc Nephrol. 2000, 11:616-624.

16. Roczniak A, Fryer JN, Levine DZ, Burns KD: Downregulation of neuronal nitric oxide synthase in the rat remnant kidney. J Am Soc Nephrol. 1999, 10:704-713.

17. Tain ZL, Freshour G, Dikalova A, Griendling K, Baylis C: Vitamin E reduces glomerulosclerosis, restores renal neuronal NOS, and suppresses oxidative stress in the $5 / 6$ nephrectomized rat. Am. J. Physiol. Renal Physiol. 2007, 292:F1404-F1410.

18. Mendoza MGA, Castillo-Henkel C, Medina-Santillan R, Jarillo Luna RA, Robles HV, Romo E, Rios A, Escalante B: Kidney damage after renal ablation is worsened in endothelial nitric oxide synthase (-/-) mice and improved by combined administration of L-arginine and antioxidants. Nephrology 2008, 13:218-27.

19. Wilcox CS: Effects of tempol and redox-cycling nitroxides in models of oxidative stress. Pharmacol. Ther. 2010, 126:119-145.

20. Roson MI, Della Penna SL, Cao G, Gorzalczany S, Pandolfo M, Toblli JE, Fernandez BE: Different protective actions of losartan and tempol on the renal inflammatory response to acute sodium overload. J. Cell. Physiol. 2010, 224:41-48.

21. Jovanovic DB, Jovovic D, Varagic J, Dimitrijevic J, Dragojlovic Z, Djukanovic L: Slowing the progression of chronic renal insufficiency with captopril in rats with spontaneous arterial hypertension and adriamycin nephropathy. Srp Arh Celok Lek 2002, 130:73-80.

22. Mihailović-Stanojević N, Jovović D, Miloradović Z, Grujić-Milanović J, Jerkić M, MarkovićLipkovskiJ: Reduced progression of adriamycin nephropathy in spontaneously hypertensive rats treated by losartan. Nephrol Dial Transplant 2009, 24:1142-50.

23. Karanovic D, Grujic-Milanovic J, Miloradovic Z, Ivanov M, Jovovic D, Vajic UJ, Zivotic M, Markovic-Lipkovski J, Mihailovic-Stanojevic N: Effects of single and combined losartan and tempol treatments on oxidative stress, kidney structure and function in spontaneously hypertensive rats with early course of proteinuric nephropathy. PLoS One 2016, 11:e0161706.

24. Green LC, Wagner DA, Glogowski J, Skipper PL, Wishnok JS, Tannenbaum SR: Analysis of nitrate, nitrite, and [15N]nitrate in biological fluids. Anal Biochem 1982, 126:131-8.

25. Nakayama T, Sato W, Kosugi T, Zhang L, Campbell-Thompson M, Yoshimura A, Croker BP, Richard J, Johnson RJ, Nakagawa T: Endothelial injury due to eNOS deficiency accelerates the progression of chronic renal disease in the mouse. Am J Physiol Renal Physiol 2009, 296:F317-F327.

26. Takahashi T, Harris RC: Role of endothelial nitric oxide synthase in diabetic nephropathy: lessons from diabetic eNOS knockout mice. J. Diabetes Res. 2014, 2014:17 pages.

27. Szabo AJ, Wagner L, Erdely A, Lau K, Baylis C: Renal neuronal nitric oxide synthase protein expression as a marker of renal injury. Kidney Int. 2003, 64:1765-1771.

28. Smith C, Merchant M, Fekete A, Nyugen HL, Oh P, Tain YL, Jon B, Klein JB, Baylis C: Splice variants of neuronal nitric oxide synthase are present in the rat kidney. Nephrol Dial Transplant 2009, 24:1422-1428.

29. Zou J, Yaoita E, Watanabe Y, Yoshida Y, Nameta M, Li H, Qu Z., Yamamoto T: Upregulation of nestin, vimentin, and desmin in rat podocytes in response to injury. Virchows. Arch. 2006, 448:485-492.

30. Van Beneden K, Van Grunsven LA, Geers C, Pauwels M, Desmouliere A, Verbeelen D, Geerts A, Van den Branden C: CRBP-I in the renal tubulointerstitial compartment of healthy rats and rats with renal fibrosis. Nephrol Dial Transplant 2008, 23:3464-71. 
31. Young BA, Burdmann EA, Johnson RJ, Alpers CE, Giachelli CM, Eng E, Andoh T, Bennett W, Couse WG: Cellular proliferation and macrophage influx precede interstitial fibrosis in cyclosporine nephrotoxicity. Kidney Int 1995, 48:439-448.

32. Carlos CP, Sonehara NM, Oliani SM, Burdmann EA: Predictive Usefulness of Urinary Biomarkers for the Identification of Cyclosporine A-Induced Nephrotoxicity in a Rat Model. PLoS ONE 2014, 9: e103660.

33. Bravo J, Quiroz Y, Pons H, Parra G, Herrera-Acosta J, Johnson RJ, Rodriguez-Iturbe B: Vimentin and heat shock protein expression are induced in the kidney by angiotensin and by nitric oxide inhibition. Kidney Int. 2003, 64:546-551.

34. Ji Z, Huang C, Liang C, Chen B, Chen S, Sun W: Protective effects of blocking reninangiotensin system on the progression of renal injury in glomerulosclerosis. Cell. Mol. Immunol. 2005, 2:150-154.

35. Ozen S, Usta Y, Sahin-Erdemli I, Orhan D, Gumusel B, Yang B, Gursoy Y, Tulunay O, Dalkara T, Bakkaloglu A, El-Nahas M: Association of nitric oxide production and apoptosis in a model of experimental nephropathy. Nephrol Dial Transplant 2001, 16:32-38.

\section{EFEKTI LOSARTANA, TEMPOLA I NJIHOVE KOMBINACIJE NA EKSPRESIJU ENZIMA SINTEZE AZOT MONOKSIDA U BUBREZIMA U ANIMALNOM MODELU HRONIČNE BUBREŽNE SLABOSTI}

KARANOVIC Danijela, GRUJIC-MILANOVIC Jelica, MILORADOVIC Zoran, IVANOV Milan, JOVOVIC Djurdjica, VAJIC Una-Jovana, CIROVIC Sanja, MARKOVIC-LIPKOVSKI Jasmina, MIHAILOVIC-STANOJEVIC Nevena

Snižena ekspresija enzima sinteze azotnog monoksida (NOS) kao i njegova smanjena raspoloživost u bubrezima mogu dovesti do progresije hronične bubrežne bolesti. Cilj ove studije je bio ispitati efekte losartana, tempola i kombinovane terapije na ekspresiju tri izoforme NOS, kao i povezanost NO sistema sa funkcijom i strukturom bubrega u ranoj fazi hronične bubrežne slabosti izazvane adrijamicinom (ADR) kod pacova sa urodjenom hipertenzijom. Pacovi su bili rasporedjeni u kontrolnu i još četiri grupe koje su bile tretirane ADR. Životinje su potom primale vodu, losartan (L, selektivni blokator angiotenzin II tip 1 receptora), tempol ( $\mathrm{T}$, stabilni nitroksid radikal) ili $\mathrm{T}+\mathrm{L}$ (gavažom) tokom narednih šest nedelja. Smanjene ekspresije svih izoformi NOS izazvane ADR bile su značajno povećane nakon tretmana losartanom ili tempolom i praćene smanjenom proteinurijom. Kombinovani tretman je doveo do smanjene ekspresije konstitutivnih izoformi NOS, dok je povećanje ekspresije inducibilne NOS bilo praćeno povišenom koncentracijon nitrita u tkivu bubrega i značajnim smanjenjem glomerulske filtracije. Za razliku od kombinovanog, pojedinačni tretmani losartanom ili tempolom sprečili su de novo sintezu vimentina, izazvanu ADR, u glomerulima, 
tubulima i intersticijumu. Zaključili smo da su pojedinačni tretmani, nasuprot kombinovanom, efikasniji u očuvanju bioraspoloživosti NO, kao i usporavanju progresije hronične bubrežne slabosti. 